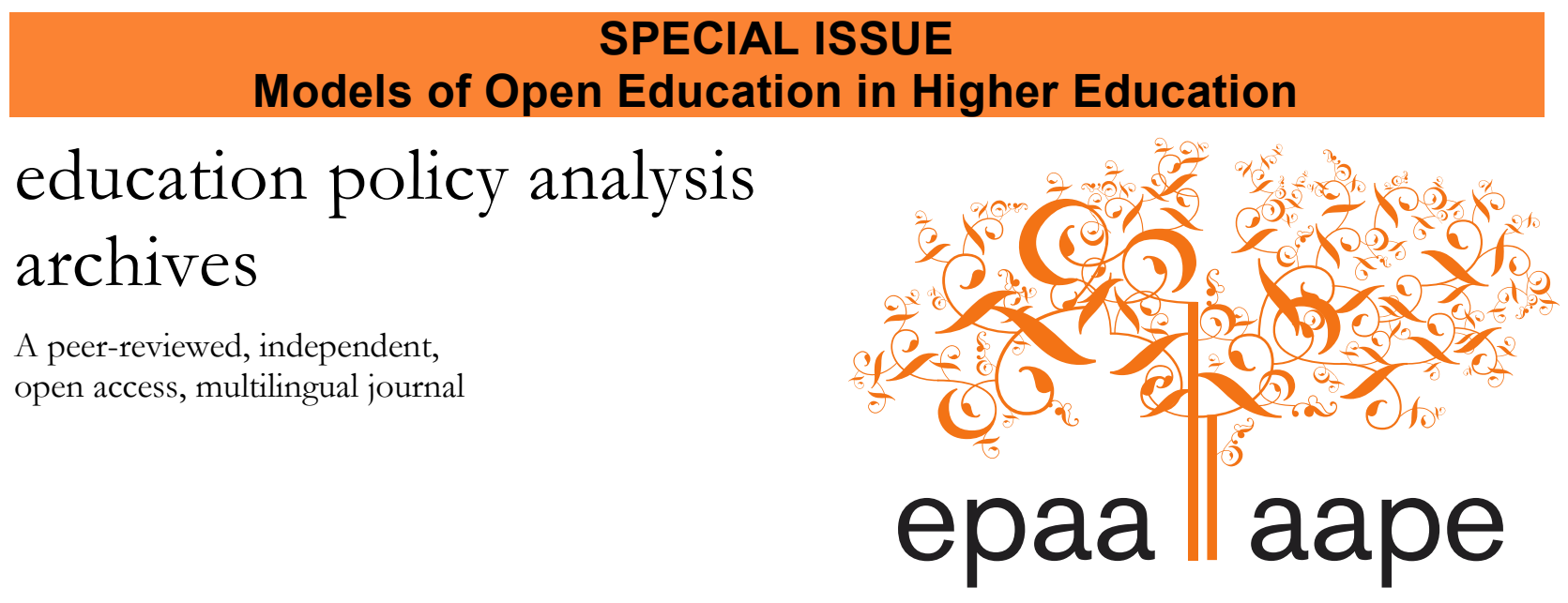

Arizona State University

\title{
Assessing the Potential for Openness: A Framework for Examining Course-level OER Implementation in Higher Education
}

\author{
Kate Judith \\ \& \\ David Bull \\ University of Southern Queensland \\ Australia
}

Citation: Judith, K. \& Bull, D. (2016). Assessing the potential for openness: A framework for examining course-level OER implementation in higher education. Education Policy Analysis Archives, 24(42). http://dx.doi.org/10.14507/epaa.24.1931 This article is part of EPAA/AAPE's Special Issue on Models of Open Education in Higher Education Guest Co-Edited by Dr. Lisa Petrides and Dr. Cynthia Jimes.

\begin{abstract}
The implementation of open educational resources (OER) at the course level in higher education poses numerous challenges to education practitioners-ranging from discoverability challenges to the lack of knowledge on how to best localize and utilize OER as courseware. Drawing on case studies of OER initiatives globally, the article discusses field-tested solutions to addressing those challenges at the faculty level, the programmatic level, and institutional level. The article concludes with an ontological framework that highlights the importance of weighing the efficiencies afforded by a higher level of institutional control in OER implementation efforts, with the need for individual freedom on behalf of faculty to creatively use and adapt OER.
\end{abstract}


Keywords: OER; Open Educational Resources; case studies; reusability; collaboration; higher education; public policy; instructional materials and practices

Evaluando el potencial de lo "abierto": una estructura para examinar la implementación de los Recursos Educacionales Abiertos al nivel de curso en educación post-secundaria

Resumen: La implementación de recursos educativos abiertos (REA) al nivel de curso en educación post-secundaria genera dificultades numerosas para los profesionales de la educación. Basándose en una revisión de la literatura vinculada a la implementación de los REA en programas de educación superior a nivel mundial, los autores identifican los principales desafíos que enfrentan los profesionales de educación, así como las estrategias para resolverlos. Por examinar las estrategias de implementación derivadas de la literatura previa, los autores identifican tipos variados de apoyo, los cuales se presentan como un continuum ontológico para asistir a los desarrolladores de los REA y quienes que toman decisiones institucionales, en cuanto a determinar métodos efectivos y políticas para cultivar prácticas educativas abiertas. El artículo concluye con una discusión de las implicaciones del continuum con respeto a los niveles de control y riesgo conllevado en utilizar el diverso rango de estrategias examinadas.

Palabras clave: REA; Recursos Educativos Abiertos; estudios de caso; reutilización; colaboración; educación post-secundaria; políticas públicas; materiales de instrucción y practicas

Avaliando o potencial do "aberto": um enquadramento para examinar a implementação dos REA ao nível do curso na educação superior

Resumo: A implementação dos recursos educativos abertos ao nível do curso na educação superior apresenta desafios numerosos para os professionais de educação. Baseado numa revisão da literatura ligada à implementação dos REA em programas de educação superior á nível mundial, os autores identificam os principais desafios na implementação dos REA que enfrentam os professionais da educação assim como estratégias para resolvê-los. Ao examinar as estratégias de implementação aprendidas a partir da literatura, os autores identificam diferentes tipos de apoio que eles apresentam como um contínuo ontológica para ajudar os desenvolvedores de REA e os tomadores de decisões institucionais em determinar métodos e políticas eficazes para cultivar práticas educativas abertas. $\mathrm{O}$ artigo termina com uma discussão das implicações desse contínuo com respeito aos níveis de controle e risco implicados em utilizando o rango diverso das estratégias examinadas.

Palavras chave: REA; Recursos Educacionais Abertos; estudos de caso; reusabilidade; colaboração; educação superior; política publica; materiais de ensino y praticas

\section{Introduction}

Over the past decade the "open" approach to education has been embraced by a growing number of academics and practitioners involved in the provision of higher education. What began a little over a decade ago with the aggregation of open educational resources (OER) in online repositories has morphed into a movement to promote not only new teaching materials and resources, but also open teaching and learning practices extending to all aspects of higher education.

The majority of the literature addressing the OER movement focuses upon this changing landscape, and the potential benefits of OER use. While this literature has been significant in driving forward the open agenda, there has been relatively little published about the practicalities of implementing openly licensed materials in higher education courses. 
This article explores effective strategies and policies for supporting the adoption and implementation of OER. The article is the result of a meta-analysis of existing case studies within the literature, focusing on OER implementation initiatives in higher education courses, the difficulties encountered in implementing OER, and the strategies applied in addressing those challenges. In total, 20 case studies were identified-spanning the global higher education sector, from India to Sub-Saharan Africa, from the South Pacific to the United States. Extant literature reviews were also identified, including Armellini and Nie's (2013) review of studies of OER applications by UK practitioners; Mawoyo and Butcher's (2012) investigation of processes of involved in producing and sharing OER in Africa, the USA, and the UK; and White and Manton's (2011) study of faculty use or promotion of OER at UK universities. Finally, the authors' own experiences integrating OER into a tertiary preparation program course at the University of Southern Queensland (USQ) served as input into the examination of this literature.

The article first identifies the challenges involved in OER implementation in higher education courses, as cited within the literature, as well as strategies for responding to those challenges. Next, the article presents a framework for assessing the strategies, in order to differentiate the varying types and degrees of supports and requirements involved in OER implementation. The discussion then presents a continuum of openness, which pays heed to the degrees of control, efficiency, and risk entailed in the range of strategies. The article concludes with a discussion of the implications of that continuum for OER developers and institutional decision makers seeking to determine the best methods and policies for supporting the adoption of open practices in higher education.

\section{Strategic Responses to Challenges Involved in Course Level OER Implementation}

Over the past decade, numerous studies have emerged within the literature addressing the challenges involved in OER implementation in higher education (e.g., Falconer, McGill, Littlejohn, \& Boursinou, 2013; Hatakka, 2009; Sinclair, Joy, Yau, \& Hagan, 2013). In examining this literature, five key categories of challenge emerge: challenges related to the localization and contextualization of OER, to faculty's ability to identify suitable, high quality OER, and to the challenges related to use permissions, discoverability, and practitioner self efficacy in using OER. The following sections elaborate these five categories of challenges in greater detail and present strategic responses to those challenges.

\section{Contextualization Challenges}

Much of the literature addressing OER implementation in higher education highlights challenges associated with faculty's ability to localize and contextualize OER to meet, for example, their student learning needs, their local teaching and pedagogical requirements, or the cultural or language-related needs present in their classrooms (Barrett et al., 2009; Hatakka, 2009; Jimes, 2008; Maktin, 2009; Omollo, Rahman, \& Yebuah, 2012; Ossianilsson \& Creelman, 2012).

The literature points to several strategic responses that OER initiatives have employed to address contextualization and localization challenges. Athabasca University, for example, established mechanisms to help faculty match appropriate resources to the specific classroom contexts in which they were needed (Ives \& Pringle, 2013). Further, toward addressing localization challenges, the Teacher Education in Sub-Saharan Africa (TESSA) project, created modular production templates for faculty to use in designing course unit OER across a wide range of contexts (Wolfendon, 2012). These templates included two distinct knowledge areas: generic global knowledge and locally contextualized knowledge (Wolfenden, 2012). While the templates were deemed advantageous in 
providing structure and transferability, and also in reducing the likelihood of content replication, they were also seen as restrictive of perceived freedom to make significant changes to materials (Wolfendon, 2012).

Disaggregation of OER - wherein content providers parse resources into smaller content pieces - is another strategy identified in the literature for meeting localization needs. Of the 20 case studies reviewed for this article, strategic disaggregation by OER content providers was discussed in eight (Friesen \& Murray, 2013; Gourley \& Lane, 2009; Harishankar, 2012; Ives \& Pringle, 2013; Lesko, 2013; Levey, 2012; Sapire, Reed, \& Welch, 2012; Schmidt-Jones, 2012). Some of institutions employing this strategy adopted it because they discovered that this was the predominant way in which their existing OER were being used (Harishankar, 2012; Levey, 2012). While the literature reveals that OER that is available in a modular or disaggregated structure are more readily useful across contexts (Hatakka, 2009; Masterman et al., 2011; Ossiannilsson \& Creelman, 2012; Sinclair et al., 2013), disaggregated resources may be too discrete, and thus lack the contextual information that is needed to make them comprehensible and usable on their own (Bundy, 2004; Friesen 2004; Sloep, 2004; Wiley, 2013).

\section{Challenges Related to the Identification of Suitable OER}

An additional area of challenge that surfaced from the literature review centered on concerns regarding the general quality of the resources, the suitability of resources in adequately meeting learning objectives for courses, and the technical appropriateness or effectiveness of resources.

In addressing challenges related to the identification of high quality OER, several initiatives have employed templates to prescribe quality standards for structural, pedagogical, and technical aspects of OER production (Kanchanaraksa et al., 2009; Wolfenden, 2012). Formal review processes, involving faculty and peers, have also played an important role in addressing quality concerns (Kanchanaraksa et al., 2009; Wolfenden, 2012). Likewise, informal peer review processes, including crowdsourced ratings and reviews, have been identified as important strategies for quality assurance (Ossiannilsson \& Creelman, 2012). Examples include Open University's Labspace, which allows OER users to review and repurpose materials before they are further shared online (Gourley \& Lane, 2009; Lane, 2012), and Athabasca University's online virtual social learning environment, "The Landing," which invites students to review and contribute to course content, toward improved OER quality (Ives \& Pringle, 2013).

Other mechanisms for addressing suitability and quality concerns include Open University's development of a cooperative partnership with the British Broadcasting Corporation to create high quality video and online resources (Lane, 2012; Lane \& Law, 2011). Furthermore, to enable easy access to high-use OER items within an established range of quality, Johns Hopkins Bloomberg School of Public Health implemented an internally accessible OER repository (Kanchanaraksa et al., 2009).

Finally, in terms of the technical suitability of resources, and specifically meeting challenges such as Internet capacity constraints that limit access to rich, multimedia resources, the University of the South Pacific (USP) developed a resource quality testing strategy that resulted in the design of contingency plans, such as preloading learning materials onto tablets and onto a local intranet, to mitigate connectivity issues at its institution (Koroivulaono, 2014).

\section{Discoverability Challenges}

The ability to discover and identify the resources most appropriate to a user's particular needs remains a major challenge in the OER space. Dichev and Dicheva (2012) investigated several major OER search engines and repositories and found them lacking in one or more of the essential 
functionalities required to effectively discover, identify, and retrieve resources. They specifically note that the metadata records associated with the resources referred mostly to the content, with very little reference to its use (Dichev \& Dicheva, 2012). Atenas and Havemann (2013) conducted a similar analysis, finding that existing peer review and user evaluation tools were limited in supporting OER discoverability.

Strategies for addressing discoverability challenges are outlined in the OER implementation literature. The provision of specialists within the realm of library and information technology support plays an important role in this area (Levey, 2012; Omollo, Rahman \& Yebuah, 2012). For example, Levey (2012) suggests using libraries to coordinate OER resource searching to save the time of overworked academics. Levey (2012) cites research conduted at the University of Illinois, which found that a majority of OER users surveyed through the library website had discovered open materials via a keyword search from a general web search (Levey, 2012). Moreover, the research indicated that users searching in this way sought specific materials, not courses, which highlights the importance of appropriate metadata schemas (Levey, 2012).

Much work is underway to develop improved metadata schemas. Sloep (2004) assessed various barriers to the use of OER across courses, and found that the limitations of metadata classification do not enable the kinds of discoverability needed by educators involved in creating courses. Sloep (2004) suggests that what is needed to improve discoverability is a meta-language that captures pedagogical approaches, without becoming too specific. Sloep (2004) proposes categories based on "didactic scenarios," such as the role for which the OER is appropriate (e.g., student or teacher), the environment to which the OER is suited (e.g., in-class, online, in a peer group), the services required (e.g., a chat facility or a collaborative learning environment), and properties (e.g., run-time and scale). As Sloep (2004) suggests, such didactic scenarios would render OER more discoverable.

\section{Challenges Related to Use Permissions}

According to Bossu, Brown, and Bull (2012), the absence of explicit institutional policies to clarify use permissions has limited the adoption and use of OER. Furthermore, 8 of the 20 case studies reviewed for this article identified copyright and intellectual property issues as a key area of challenge for OER uptake and use (Barrett et al., 2009; Kanchanaraksa, Gooding, Klaas, \& Yager, 2009; Keats, 2009; Lane, 2012; Ives \& Pringle, 2013; Lesko, 2013; Myers, 2012; Schuwer \& Mulder, 2009).

OER users may be unaware of the use permissions associated with the materials they are using. In a survey of faculty at South African Higher Education Institutions (SAHEI), Lesko (2013) found that only $52 \%$ of respondents were aware of the use permissions associated with the open courseware they were using. Other scholars point to the confusion that arises for OER users when single resources have multiple permissions assigned to them-for example, when single resources with several embedded elements have a complex rights profile (Barrett et al., 2009; Kanchanaraksa et al., 2009).

A study at Johns Hopkins Bloomberg School of Public Health found that copyright management has been the most time-consuming aspect of the OER publishing process because it entails finding a unique solution for each object (Kanchanaraksa et al., 2009). Moreover, at the institutional level, that copyright management often results in the need to remove "good educational content" (Kanchanaraksa et al., 2009, p. 42), which is exacerbated by the lack of protocols and understanding around how to seek permissions from rights holders who may be willing to open up their materials. In terms of individual faculty members, Lesko (2013) notes that those who are producing OER are often ill informed about licensing options for sharing their work. 
A variety of strategic responses to copyright challenges were mentioned in the literature. For example, Athabasca University has moved away from using third party resources that cannot be accessed via a web link, and instead provides simple URL links or RSS feeds where possible (Ives \& Pringle, 2013). In contrast, Open Universitiet Netherlands has moved towards utilizing OER predominantly created by its faculty and staff to avoid the complexities of use permissions (Schuwer \& Mulder, 2009). At Open University UK, this OER production strategy involves teams of experts, including intellectual property experts, working collaboratively alongside faculty as content developers (Lane, 2012).

\section{Knowledge-Related Challenges}

This category of challenges is centered on those related to lack of practitioner knowledge and self-efficacy in using OER. The Joint Research Centre of the European Commission lists insufficient digital literacy and lack of awareness regarding possibilities for OER use as barriers to OER uptake, but notes that these particular barriers are decreasing in importance (Falconer et al., 2013). However others, for example Panke (2011) and Armellini and Nie (2013), suggest that challenges stemming from lack of user knowledge remain significant and require further attention within the realm of OER.

Collaboration among educators can serve as a strategy for addressing knowledge-related challenges, and is often supported through professional development workshops on collaborative OER sharing and use for subject specialists (Lesperance, 2012; Sapire, Reed, \& Welch, 2012). For example, intensive workshops were implemented at Virtual University for Small States of the Commonwealth (VUSSC), where faculty leaders from participating programs received comprehensive training on OER and were tasked with sharing their knowledge with colleagues upon their return to their home countries (Lesperance, 2012). Likewise, the South African Institute of Distance Education (SAIDE) initiative promoted collaboration among its mathematics teachers to develop knowledge around OER, as well as engagement with the project goals (Sapire, Reed, \& Welch, 2012). In this way, collaborative networks, often disciplinary in focus, have formed to share relevant OER information (Brent, Gibbs, \& Gruszczynska, 2012).

Other examples of professional development supports include United Nations University's "starter pack" to support faculty and staff in creating OER-rich online courses, and its international steering group spanning several research institutes to foster collaboration around OER integration into existing research and training activities (Barrett et al., 2009). Additionally, Johns Hopkins Bloomberg School of Public Health offers a staff-accessible, centrally managed repository to facilitate OER adaptation for students with disabilities (Kanchanaraksa et al., 2009).

In addition to supports related to professional development, institutions also provide tools to assist staff in achieving self-efficacy in implementing OER (Barrett et al., 2009; Kanchanaraksa et al., 2009; Mawoyo \& Butcher, 2012). These tools, often developed by institutional OER specialists, include compilations of exemplary OER and flowcharts for determining and assessing use permissions on resources (Barrett et al., 2009; Kanchanaraksa et al., 2009; Mawoyo \& Butcher, 2012).

Finally, to promote institution-wide knowledge of OER, Athabasca University hosted the 2011 UNESCO/Commonwealth of Learning Chair in OER. This assisted in promoting knowledge of OER throughout the institution through training, support, and research in open educational practices, as well as in building relationships for such practices institutionally, nationally, and internationally (Ives \& Pringle, 2013). 


\section{Assessing the Strategies}

The foregoing discussion points to a diverse set of strategies and supports to address OER implementation challenges. Some of the strategies identified start with the individual agent or actor, while others involve leveraging collaborative relationships to support successful OER implementation. In further examining the strategies through an ontological lens, the following categories emerged - ranging from individual-level strategies, to networked or user-shaped strategies, as illustrated in Figure 1.

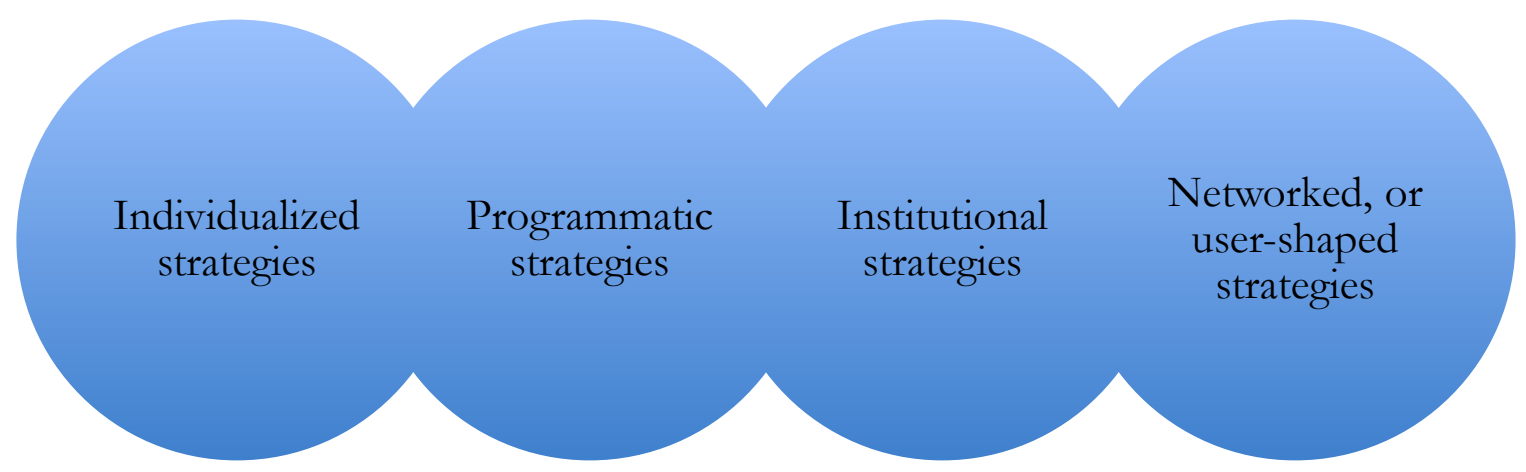

Figure 1. Framework for assessing OER implementation strategies

As illustrated, the four categories of strategies - individual, programmatic, institutional, and networked or user-shaped-demarcate increasing levels of collaborative support involved in OER implementation. In the sections that follow, strategies within each of the above categories are discussed, beginning with individual and proceeding to networked or user-shaped strategies.

\section{Individual Strategies}

Individual strategies concentrate the responsibility for solving the challenges of implementation on the individual, or on a small independent team. Within this category of strategies, for example, individual faculty members may go online to search for and explore suitable open educational resources, read help guides and tutorials on OER use, examine reviews of OER to asses quality, or nominate themselves for training to improve their OER-related skills.

As described by Levey (2012), these strategies represent an independent learning journey to improve OER-related knowledge and skills. However, individual strategies may in some cases fail to fully engage the potential of OER. Especially in terms of addressing challenges associated with copyright restrictions, individual faculty members may, for example, discount or overlook useful resources that have ambiguous use permissions (Barrett et al., 2009; Mawoyo \& Butcher, 2012), or may develop workarounds to bypass use restrictions--such as including links to copyrighted resources within their own resources. As noted above, the process of updating those links, when 
they potentially become obsolete, is time consuming and can interrupt the continuity of resource delivery (Koroivulaono, 2014; Myers, 2012).

While individual strategies may be limited in their ability to take advantage of the full potential of OER, enterprising individuals can and do successfully implement OER at the course level. Moreover, as demonstrated by several of the examples discussed in this article, institutions can fluidly accommodate and even cultivate the creative interventions of individuals.

\section{Programmatic Strategies}

Programmatic strategies harness resources and personnel already available at institutions to foster helpful working relationships toward alleviating the workloads of academic instructors. Within this category of strategies, professional development initiatives, such as the above-mentioned VUSSC OER training "boot camps," facilitate collaborative supports such as knowledge sharing (Lesperance, 2012).

The provision of appropriate experts and tools is another programmatic strategy that has been applied across several institutions (Barrett et al., 2009; Kanchanaraksa et al., 2009; Levey, 2012; Mawoyo \& Butcher, 2012; Omollo, Rahman \& Yebuah, 2012). For instance, the provision of an OER repository tailored to the institutional context, as cited above in regard to Johns Hopkins Bloomberg School of Public Health (Kanchanaraksa et al., 2009), can help academics use OER without having to become information technology experts.

The collaborative supports provided by programmatic strategies for OER implementation can relieve some of the difficulties associated with individual strategies, as programmatic strategies may begin to establish a collaborative institutional culture conducive to open educational practices. However, while programmatic strategies assist in meeting the challenges of OER implementation, they reflect a model that tackles each OER implementation challenge separately, rather than establishing a coherent, systemic approach to addressing them all.

\section{Institutional Strategies}

On a broader scale, institutional strategies systematically distribute the responsibility for solving the challenges of OER implementation, allowing faculty to rely on collaborative support systems fostered by institutional policy. Within this category of strategies, programmatic strategies, such as OER professional development, are commonly integrated into an overarching, institutionwide OER support strategy. One example of this strategy is the aforementioned creation of an international steering group at the United Nations University, which sought to foster collaboration as a mechanism for integrating OER more seamlessly across its research and training activities (Barrett et al., 2009).

As components of integrated, systemic plans, institutional strategies also influence multiple facets of student, faculty and staff experience. This multifaceted quality is demonstrated by Athabasca University's networks of communication for matching OER to appropriate contexts, including the institution's online social learning environment that invites students to contribute collaboratively toward improving resource quality, and extending to the university's 2011 UNESCO/Commonwealth of Learning Chair in OER (Ives \& Pringle, 2013).

Institutional strategies have the potential to incentivize collaboration around OER use and implementation beyond the level of the individual user. However, these strategies may conceivably limit the creative potential of individuals, as noted in the TESSA case study where the institutionwide implementation of OER templates was found to sometimes restrict the users' perceived freedom to make significant changes to the materials (Wolfendon, 2012). Moreover, institution-wide 
strategies generally require large-scale financial investment, necessitating continual research to monitor their effectiveness (Lane \& McAndrew, 2010).

\section{Networked or User-shaped Strategies}

With or without institutional support, groups of academics, content developers and others interested in open educational resources and associated use practices have coalesced to provide mutual assistance in meeting the challenges of OER implementation, especially with regard to developing practitioner knowledge and self-efficacy in OER use.

Collaborative, user-shaped networks often arise in conjunction with professional development training or disciplinary interest groups, to facilitate OER sharing and use (Brent, Gibbs, \& Gruszczynska, 2012; Lesperance, 2012; Sapire, Reed, \& Welch, 2012). They involve some degree of relinquished institutional, managerial or creator control, and reassignment of that power to a network of users. The disaggregation of OER by groups of users falls within this category of strategies, as a mechanism to addressing user needs for localized, high quality content (Friesen \& Murray, 2013; Harishankar, 2012; Ives \& Pringle, 2013; Lesko, 2013; Levey, 2012; Sapire, Reed, \& Welch, 2012; Schmidt-Jones, 2012). Through disaggregation, innovation and creativity may be sparked, as the loss of meaning resulting from the fragmentation of formerly coherent OER may correspond to an increase in the potential for new meaning to be created from the fragments.

Finally, crowd-sourced quality control is a less common user-shaped approach to specifically addressing OER suitability and quality concerns. Although its potential was widely anticipated (Ossianilsson \& Creelman, 2012), it has not surfaced as a predominant solution to OER implementation challenges, potentially indicating that it is currently considered a step too far towards a reliance on bottom up, user-oriented collaborative OER practices.

Networked and user-shaped strategies, while sometimes harnessed by programmatic or institutional strategies, exceed the scale of the helpful working relationships cultivated by those strategies. Networked and user-shaped strategies involve individual users as participants in improvised collaborative self-organizing networks. Here, one finds complex systemic interactions that can foster the emergence of new phenomena through the interactions of many elements, none of which takes a leading role (Johnson, 2001). These approaches can go further to harness the potential for innovation inherent in the use of open educational resources. On the other hand, as the ability to determine outcomes is lost, there is a risk of inefficiency, and the ability of these strategies to solve the challenges of context, copyright, suitability, discoverability, and knowledge becomes less predictable.

The categories of strategies presented here-individual, programmatic, institutional, and user-shaped-represent salient responses that impact the practical processes of OER implementation at the course level. On the whole, the types and degrees of collaborative support involved in these strategies demonstrate widespread adaptability and scope for innovation toward effective solutions to the most common OER implementation challenges.

\section{A Continuum of Openness}

As the above discussion demonstrates, OER implementation support takes many forms, including ad hoc teamwork, the cultivation of helpful working relationships, the establishment of overarching policies, and the formation of self-organizing networks. The diverse range of strategies for addressing challenges involved in implementing OER into higher education courses may be best understood as extending along a continuum of openness in education. At one end of this continuum, strong institutional influence supports effective but restrictive responses to OER 
integration. At the other end, high risk is accepted as part of moving towards user-directed open practices.

An example of a high influence, low risk strategy is that employed by the TESSA project in coordinating the production of OER that are suitable and adaptable for diverse contexts (Wolfenden, 2012). The top-down standards that included the use of templates for all OER and the requirement for local content were reported as successful in achieving these goals. On the other hand, this degree of control was found in some cases to limit the potential for innovation or imagination in the design of the resources and courses (Wolfenden, 2012).

At the other end of the continuum are strategies such as crowd-sourced quality control, or user-generated repository search parameters for OER suitability. Here, the outcomes will be fluid, changing and unpredictable. At this end of the openness spectrum, there is scope for the unexpected to emerge, but also a risk of time and resource wastage and inefficiency. A selection of strategies is represented on this continuum in Figure 2.

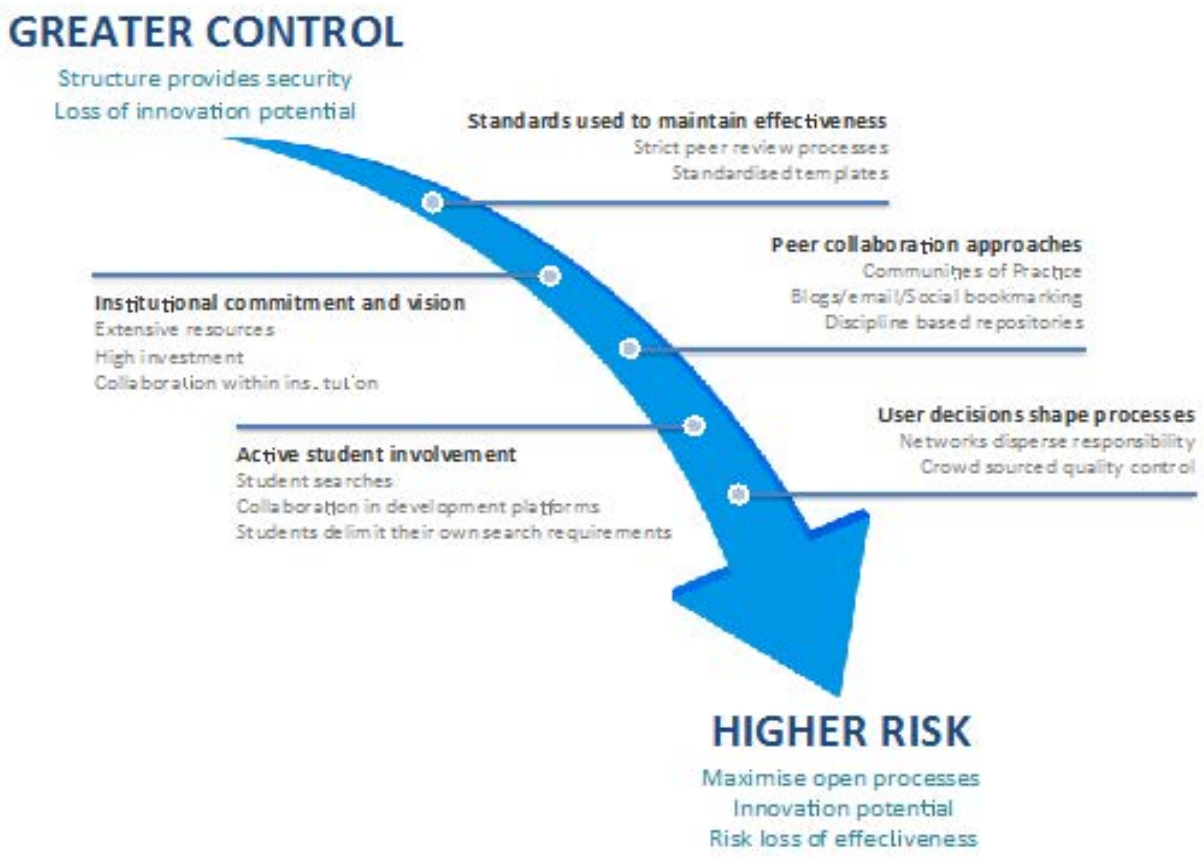

Figure 2. A continuum of openness

While strategies at either end of this continuum are likely to be appropriate choices for contexts where either high short-term efficiency is required, or high risk can be tolerated to support the potential emergence of innovation, strategies arrayed through the middle of the continuum are likely to be more adaptable within a wider range of contexts. Most applications of a strategy designed to incorporate openness into learning materials will fall within the central regions of this continuum. For example, most practitioners are likely to draw upon the expertise of their peers, actively engage with students, and utilize the coordinated facilities of their institutions. However, 
practitioners may be less likely to rely solely upon either high risk or strictly controlled structures as these may act to limit the potential of their strategies. The use of a range of strategies enhances efficacy in identifying, redesigning and adopting suitable materials. As the implementation of OER in higher education occurs in a variety of contexts globally, it is appropriate that a diverse and wide range of strategies may be likely to produce the most effective results.

\section{Conclusion}

This article has revealed a wide range of strategies for addressing challenges associated with implementing OER into existing higher education courses--from approaches driven by individuals to those supported by self-organizing collaborative networks. The article has also offered a continuum of openness to facilitate understanding of some of the potential advantages and disadvantages of addressing OER implementation challenges through strategies situated across these varied ontological levels.

The continuum of openness may be helpful to institutional decision makers, education practitioners, and OER developers seeking to determine the best policies and methods for supporting the adoption of open practices. Pragmatic assessment of strategic capacities for realizing the potential of openness in educational practices may benefit from weighing the efficiencies afforded by a higher level of institutional, structural, or individual control, against a lower potential for innovation and adaptability, as identified at one end of the support continuum. Likewise, at the other end of the continuum, a higher potential for innovation and adaptability must be weighed against a risk of unpredictable efficiency. While strategies at either extreme of the continuum are likely to offer significant strengths within certain limited contexts, those strategies located in the middle of the continuum are likely to provide the balance-between efficiency, capacity for innovation, and adaptability.

\section{References}

Armellini, A., \& Nie, M. (2013). Open educational practices for curriculum enhancement. Open Learning: The Journal of Open, Distance and e-Learning, 28(1), 7-20. http://dx.doi.org/10.1080/02680513.2013.796286

Atenas, J., \& Havemann, L. (2013). Quality assurance in the open: An evaluation of OER repositories. The International Journal for Innovation and Quality in Learning, 2013(2). Retrieved from http://papers.efquel.org/index.php/innoqual/article/view/30

Barrett, B., Grover, V., Janowski, T., van Lavieren, H., Ojo, A., \& Schmidt, P. (2009). Challenges in the adoption and use of OpenCourseWare: Experience of the United Nations University. Open Learning: The Journal of Open and Distance Learning, 24(1), 31-38. doi: 10.1080/02680510802627803.

Bossu, C., Brown, M., \& Bull, D. (2012). Do open educational resources represent additional challenges or advantages to the current climate of change in the Australian higher education sector? Paper presented at the Ascilite 2012: Future Challenges, Susta inable Futures, Wellington, NZ.

Brent, I., Gibbs, G., \& Gruszczynska, A. K. (2012). Obstacles to creating and finding open educational resources: The case of research methods in the social sciences. Journal of Interactive Media in Education JIME, 2012(5).doi:http://doi.org/10.5334/2012-05.

Bundy, A. (2004). Australian and New Zealand information literacy framework: Principles, standards and practice. Adelaide: Australian and New Zealand Institute for Information Literacy. 
Retrieved from: http://www.caul.edu.au/content/upload/files/infoliteracy/InfoLiteracyFramework.pdf

Dichev, C., \& Dicheva, D. (2012). Open educational resources in computer science teaching. Paper presented at the Proceedings of the 43rd ACM technical symposium on Computer Science Education, Raleigh North Carolina. doi:10.1145/2157136.2157314.

Falconer, I., McGill, L., Littlejohn, A., \& Boursinou, E. (2013). Overview and analysis of practices with open educational resources in adult education in Europe. Joint Research Centre - Institute for Prospective Technological Studies. doi:10.2791/34193.

Friesen, N. (2004). Three objections to learning objects. In R. McGreal (Ed.), Online education using learning objects (pp. 59-70). London and New York: Routledge.

Friesen, N., \& Murray, J. (2013). “Open learning 2.0?”: Aligning student, teacher and content for openness in education. E-Learning and Digital Media, 10(2). doi:10.2304/elea.2013.10.2.200.

Gourley, B., \& Lane, A. (2009). Re-invigorating openness at The Open University: The role of open educational resources. Open Learning: The Journal of Open and Distance Learning, 24(1), 57-65. doi:10.1080/02680510802627845.

Harishankar, V. B. (2012). Tracing the trajectory of OER in India: reflections on three initiatives. In J. Glennie, K. Harley, N. Butcher \& T. van Wyk (Eds.), Open educational resources and change in higher education: Reflections from practice (pp. 41-56). Vancouver: Commonwealth of Learning.

Hatakka, M. (2009). Build it and they will come? Inhibiting factors for reuse of open content in developing countries. The Electronic Journal of Information Systems in Developing Countries, 37(5), 1-16. Retrieved from http://www.ejisdc.org/ojs2.../index.php/ejisdc/article/view/545

Hockings, C., Brett, P. \& Terentjevs, M. (2012). Making a difference - inclusive learning and teaching in higher education through open educational resources. Distance Education, 33(2), 237-252. doi:10.1080/01587919.2012.692066.

Ives, C., \& Pringle, M. M. (2013). Moving to open educational resources at Athabasca University: A case study. International Review of Research in Open and Distance Learning,14(2), 1-13. Retrieved from http://www.irrodl.org/index.php/irrodl/article/view/1534

Jimes, C. (2008). Travel well open educational resources: A presentation of ongoing research. Paper presented at iSummit '08, Sapporo, Japan. Retrieved from http://www.iskme.org/sites/default/files/travel-well-open-educational-resources 1.pdf

Johnson, S. (2001). Emergence: The connected lives of ants, brains, cities and software. Sydney: Penguin.

Kanchanaraksa, S., Gooding, I., Klaas, B., \& Yager, J. (2009). Johns Hopkins Bloomberg School of Public Health OpenCourseWare. Open Learning: The Journal of Open and Distance Learning, 24(1), 39-46. doi:10.1080/02680510802627811.

Keats, D. (2009). The road to free and open educational resources at the University of the Western Cape: A personal and institutional journey. Open Learning: The Journal of Open and Distance Learning, 24(1), 47-55. doi:10.1080/02680510802627829

Koroivulaono, T. (2014). Open educational resources: A regional university's journ ey. RUSC. Universities and Knowledge Society Journal, 11 (3), 91-107. doi:10.7238/rusc.v11i3.2121

Lane, A. and Law, A. (2011). Sharing and reusing rich media: lessons from The Open University. OCWC Global Conference, 04-06 May 2011, Boston, Massachusetts. Retrieved from: http://oro.open.ac.uk/29199/ 
Lane, A. (2012). Case studies on institutional open approaches: The Open University. The Open University: Open research online JISC. Retrieved from http://oro.open.ac.uk/id/eprint/33245

Lane, A., \& McAndrew, P. (2010). Are open educational resources systematic or systemic change agents for teaching practice? British Journal of Educational Technology, 41(6), 952-962. doi:10.1111/j.1467-8535.2010.01119.x.

Lesko, I. (2013). The use and production of OER \& OCW in teaching in South African higher education institutions: A case study. Open Praxis, 5(2). doi:http://dx.doi.org/10.5944/openpraxis.5.2.52

Lesperance, J. T. (2012). The Virtual University for Small States of the Commonwealth (VUSSC): OER within a transnational qualifications framework. In J. Glennie, K. Harley, N. Butcher \& T. van Wyk (Eds.), Open educational resources and change in higher education: reflections from practice (pp. 169-172). Vancouver: Commonwealth of Learning.

Levey, L. (2012). Finding relevant OER in higher education: A personal account. In J. Glennie, K. Harley, N. Butcher \& T. van Wyk (Eds.), Open educational resources and change in bigher education: Reflections from practice (pp. 125-140). Vancouver: Commonwealth of Learning.

Maktin, G. W. (2009). Open content, open courses, open degrees. Paper presented at the Transcending Boundaries, UCEA 94th Annual Conference, Boston, Massachusetts.

Masterman, L., Wild, J., White, D., \& Manton, M. (2011). The impact of OER on teaching and learning in UK universities: Implications for learning design. Paper presented at the 6th International LAMS \& Learning Design Conference 2011: Learning design for a changing world, Sydney. Retrieved from http://lams2011sydney.lamsfoundation.org/docs/RP/Masterman Wild.pdf

Mawoyo, M., \& Butcher, N. (2012). Sharing existing teaching materials as OER: Key considerations from practice. In J. Glennie, K. Harley, N. Butcher \& T. van Wyk (Eds.), Open educational resources and change in higher education: Reflections from practice (pp. 199-216). Vancouver: Commonwealth of Learning.

Myers, J. (2012). OER and teaching occupational and environmental health at the post-graduate level to medical practitioners at the University of Cape Town. In J. Glennie, K. Harley, N. Butcher \& T. van Wyk (Eds.), Open educational resources and change in higher education (pp. 193-198). Vancouver: Commonwealth of Learning.

Omollo, K. L., Rahman, A., \& Yebuah, C. A. (2012). Producing OER from scratch: The case of health sciences at the University of Ghana and the Kwame Nkrumah University of Science and Technology. In J. Glennie, K. Harley, N. Butcher \& T. van Wyk (Eds.), Open educational resources and change in higher education: Reflections from practice (pp. 57-74). Vancouver: Commonwealth of Learning.

Ossianilsson, E., \& Creelman, A. (2012). OER, resources for learning - experiences from an OER project in Sweden. European Journal of Open, Distance and E-Learning, 17(42).

Retrieved from http://www.eurodl.org/?p=current\&article $=494$

Panke, S. (2011). An expert survey on the barriers and enablers of open educational practices. eLearning Papers, 23. Retrieved from http://www.openeducationeuropa.eu/en/article/An-Expert-Survey-on-the-Barriers-andEnablers-of-Open-Educational-Practices.

Sapire, I., Reed, Y., \& Welch, T. (2012). Collaborative materials design, adaptation and take-up: A case study of a South African mathematics teacher education OER project. In J. Glennie, K. Harley, N. Butcher \& T. van Wyk (Eds.), Open educational resources and change in 
higher education: Reflections from practice (pp. 75-90). Vancouver: Commonwealth of Learning.

Schmidt-Jones, C. A. (2012). An open educational resource supports a diversity of inquiry-based learning. The International Review of Research in Open and Distance Learning, 13(1), 1-16. Retrieved from http://www.irrodl.org/index.php/irrodl/article/view/1141/2074

Schuwer, R., \& Mulder, F. (2009). OpenER, a Dutch initiative in open educational resources. Open Learning: The Journal of Open and Distance Learning, 24(1), 67-76. doi:10.1080/02680510802627852.

Sinclair, J., Joy, M., Yau, J., \& Hagan, S. (2013). A practice-oriented review of learning objects. IEEE Transactions on Learning Technologies, 6(2), 177-192. doi:10.1109/TLT.2013.6.

Sloep, P. (2004). Reuse, portability and interoperability of learning objects. In R. McGreal (Ed.), Online education using learning objects (pp. 128-137). London and New York: Routledge.

Stagg, A. (2014). OER adoption: A continuum for practice. Universities and Knowledge Society Journal, 11(3), 151-164.

White, D., \& Manton, M. (2011). Open educational resources: The value of reuse in higher education. JISC funded OER Impact study. University of Oxford. Retrieved from www.webarchive.org.uk/wayback/archive/20140614114921/http://www.jisc.ac.uk/med ia/documents/programmes/elearning/oer/OERTheValueOfReuseInHigherEducation.p $\underline{\mathrm{df}}$

Wiley, D. (2013). The reusability paradox. OpenStax CNX. Retrieved 24 May, 2015, from http://cnx.org/contents/dad41956-c2b2-4e01-94b4-4a871783b021@,19

Wolfenden, F. (2012). OER production and adaptation through networking across Sub-Saharan Africa: Learning from TESSA. In J. Glennie, K. Harley, N. Butcher \& T. van Wyk (Eds.), Open educational resources and change in higher education: Reflections from practice (pp. 91106). Vancouver: Commonwealth of Learning. 


\section{About the Authors}

\section{Kate Judith}

University of Southern Queensland

kate.judith@usq.edu.au

Kate Judith lectures in Academic Communications at the Open Access College at the University of Southern Queensland. She has been engaging with open educational practices both as a practitioner creating and reusing OER, and as a researcher with an interest in the practical applications of open access within established higher education courses.

\section{David Bull}

University of Southern Queensland

david.bull@usq.edu.au

David Bull is currently the Director of the Open Access College at the University of Southern Queensland, where he advocates for the widespread adoption of open practices for the delivery of higher education. His research interests lie primarily with issues related to equity and access policy in higher education and preparatory program curriculum development.

\section{About the Co-Guest Editors}

\section{Lisa A. Petrides}

Institute for the Study of Knowledge Management in Education

lisa@iskme.org

Lisa Petrides, Ph.D. is CEO and founder of the Institute for the Study of Knowledge Management in Education (ISKME). A former professor in the Department of Organization and Leadership at Columbia University, Teachers College, her research and teaching interests include information science, decision-making, and issues of access and equity in education. Petrides also leads OER Commons (www.oercommons.org), a digital public library of open educational resources, and a collaboration platform that supports and facilitates the creation, sharing, and modification of open educational resources. Petrides received her Ph.D. from Stanford University.

\section{Cynthia M. Jimes}

Institute for the Study of Knowledge Management in Education cynthia@iskme.org Cynthia Jimes, Ph.D., is Director of Research at the Institute for the Study of Knowledge Management in Education (ISKME), where she has led international projects over the past ten years focusing on the use and impact of open educational resources on teaching and learning. While living in Sweden and the Netherlands from 1995 to 2004, she worked in both the private and public sectors, holding positions in research consulting, teaching high school and college, and obtaining her Ph.D. in Information Science from Uppsala University in Sweden. 


\title{
SPECIAL ISSUE \\ Models of Open Education in Higher Education education policy analysis archives
}

Volume 24 Number 42 March 28, 3016

ISSN 1068-2341

\begin{abstract}
(c)
SOMIERIGHISRESERVED Readers are free to copy, display, and distribute this article, as long as the work is attributed to the author(s) and Education Policy Analysis Archives, it is distributed for noncommercial purposes only, and no alteration or transformation is made in the work. More details of this Creative Commons license are available at http://creativecommons.org/licenses/by-nc-sa/3.0/. All other uses must be approved by the author(s) or EPAA. EPAA is published by the Mary Lou Fulton Institute and Graduate School of Education at Arizona State University Articles are indexed in CIRC (Clasificación Integrada de Revistas Científicas, Spain), DIALNET (Spain), Directory of Open Access Journals, EBSCO Education Research Complete, ERIC, Education Full Text (H.W. Wilson), QUALIS A2 (Brazil), SCImago Journal Rank; SCOPUS, SOCOLAR (China).

Please contribute commentaries at http://epaa.info/wordpress/ and send errata notes to Gustavo E. Fischman fischman@asu.edu

Join EPAA's Facebook community at https://www.facebook.com/EPAAAAPE and Twitter feed@epaa_aape.
\end{abstract}




\section{education policy analysis archives editorial board}

Lead Editor: Audrey Amrein-Beardsley (Arizona State University)

Executive Editor: Gustavo E. Fischman (Arizona State University) Associate Editors: Sherman Dorn, David R. Garcia, Oscar Jimenez-Castellanos,

Eugene Judson, Jeanne M. Powers (Arizona State University)

\author{
Cristina Alfaro San Diego State \\ University \\ Gary Anderson New York \\ University \\ Michael W. Apple University of \\ Wisconsin, Madison \\ Jeff Bale OISE, University of \\ Toronto, Canada \\ Aaron Bevanot SUNY Albany \\ David C. Berliner Arizona \\ State University \\ Henry Braun Boston College \\ Casey Cobb University of \\ Connecticut
}

Arnold Danzig San Jose State University

\section{Linda Darling-Hammond}

Stanford University

Elizabeth H. DeBray University of Georgia

Chad d'Entremont Rennie Center for Education Research \& Policy

John Diamond University of Wisconsin, Madison

Matthew Di Carlo Albert Shanker Institute

Michael J. Dumas University of California, Berkeley

Kathy Escamilla University of Colorado, Boulder

Melissa Lynn Freeman Adams State College

Rachael Gabriel

University of Connecticut

Amy Garrett Dikkers University of North Carolina, Wilmington

Gene V Glass Arizona

State University

\section{Ronald Glass University of} California, Santa Cruz

Jacob P. K. Gross University of Louisville

Eric M. Haas WestEd

Julian Vasquez Heilig California State University, Sacramento Kimberly Kappler Hewitt University of North Carolina Greensboro

Aimee Howley Ohio University

Steve Klees University of Maryland

Jaekyung Lee

SUNY Buffalo

Jessica Nina Lester

Indiana University

Amanda E. Lewis University of Illinois, Chicago

Chad R. Lochmiller Indiana University

Christopher Lubienski University of Illinois, Urbana-Champaign

Sarah Lubienski University of Illinois, Urbana-Champaign

William J. Mathis University of Colorado, Boulder

Michele S. Moses University of Colorado, Boulder

Julianne Moss Deakin

University, Australia

Sharon Nichols University of Texas, San Antonio

Eric Parsons University of

Missouri-Columbia

Susan L. Robertson Bristol

University, UK

Gloria M. Rodriguez

University of California, Davis
R. Anthony Rolle University of Houston

A. G. Rud Washington State University

Patricia Sánchez University of University of Texas, San Antonio

Janelle Scott University of California, Berkeley Jack Schneider College of the Holy Cross

Noah Sobe Loyola University

Nelly P. Stromquist University of Maryland

Benjamin Superfine University of Illinois, Chicago

Maria Teresa Tatto

Michigan State University

Adai Tefera Virginia

Commonwealth University

Tina Trujillo University of California, Berkeley

Federico R. Waitoller University of Illinois, Chicago

Larisa Warhol

University of Connecticut

John Weathers University of Colorado, Colorado Springs

Kevin Welner University of Colorado, Boulder

Terrence G. Wiley Center for Applied Linguistics

John Willinsky

Stanford University

Jennifer R. Wolgemuth University of South Florida

Kyo Yamashiro Claremont Graduate University 


\section{archivos analíticos de políticas educativas consejo editorial}

Editor Ejecutivo: Gustavo E. Fischman (Arizona State University)

Editores Asociados: Armando Alcántara Santuario (Universidad Nacional Autónoma de México), Jason Beech, (Universidad de San Andrés), Antonio Luzon, Universidad de Granada

Claudio Almonacid

Universidad Metropolitana de

Ciencias de la Educación, Chile

Miguel Ángel Arias Ortega

Universidad Autónoma de la

Ciudad de México

Xavier Besalú Costa

Universitat de Girona, España

Xavier Bonal Sarro Universidad

Autónoma de Barcelona, España

Antonio Bolívar Boitia

Universidad de Granada, España

José Joaquín Brunner Universidad

Diego Portales, Chile

Damián Canales Sánchez

Instituto Nacional para la

Evaluación de la Educación, México

\section{Gabriela de la Cruz Flores}

Universidad Nacional Autónoma de México

Marco Antonio Delgado Fuentes

Universidad Iberoamericana,

México

Inés Dussel, DIE-CINVESTAV, México

Pedro Flores Crespo Universidad

Iberoamericana, México

Ana María García de Fanelli Centro de Estudios de Estado y Sociedad (CEDES) CONICET, Argentina
Juan Carlos González Faraco

Universidad de Huelva, España

María Clemente Linuesa

Universidad de Salamanca, España

Jaume Martínez Bonafé

Universitat de València, España

Alejandro Márquez Jiménez

Instituto de Investigaciones sobre la

Universidad y la Educación, UNAM,

México

María Guadalupe Olivier Tellez,

Universidad Pedagógica Nacional, México

Miguel Pereyra Universidad de

Granada, España

Mónica Pini Universidad Nacional de San Martín, Argentina

\section{Omar Orlando Pulido Chaves}

Instituto para la Investigación

Educativa y el Desarrollo Pedagógico (IDEP)

José Luis Ramírez Romero

Universidad Autónoma de Sonora, México

Paula Razquin Universidad de San

Andrés, Argentina

José Ignacio Rivas Flores

Universidad de Málaga, España
Miriam Rodríguez Vargas

Universidad Autónoma de

Tamaulipas, México

José Gregorio Rodríguez

Universidad Nacional de

Colombia, Colombia

Mario Rueda Beltrán Instituto

de Investigaciones sobre la

Universidad y la Educación, UNAM, México

José Luis San Fabián Maroto

Universidad de Oviedo,

España

Jurjo Torres Santomé,

Universidad de la Coruña, España

Yengny Marisol Silva Laya

Universidad Iberoamericana,

México

Juan Carlos Tedesco

Universidad Nacional de San

Martín, Argentina

\section{Ernesto Treviño Ronzón}

Universidad Veracruzana, México

Ernesto Treviño Villarreal

Universidad Diego Portales

Santiago, Chile

Antoni Verger Planells

Universidad Autónoma de

Barcelona, España

Catalina Wainerman

Universidad de San Andrés, Argentina

Juan Carlos Yáñez Velazco

Universidad de Colima, México 


\section{arquivos analíticos de políticas educativas conselho editorial}

Editor Executivo: Gustavo E. Fischman (Arizona State University) Editoras Associadas: Geovana Mendonça Lunardi Mendes (Universidade do Estado de Santa Catarina), Marcia Pletsch, Sandra Regina Sales (Universidade Federal Rural do Rio de Janeiro)

\author{
Almerindo Afonso \\ Universidade do Minho \\ Portugal \\ Rosanna Maria Barros Sá \\ Universidade do Algarve \\ Portugal \\ Maria Helena Bonilla \\ Universidade Federal da Bahia \\ Brasil \\ Rosa Maria Bueno Fischer \\ Universidade Federal do Rio Grande \\ do Sul, Brasil
}

\author{
Alexandre Fernandez Vaz \\ Universidade Federal de Santa \\ Catarina, Brasil

\section{Regina Célia Linhares Hostins \\ Universidade do Vale do Itajaí, \\ Brasil}

\section{Alfredo Macedo Gomes \\ Universidade Federal de Pernambuco}

Brasil

\section{Jefferson Mainardes \\ Universidade Estadual de Ponta \\ Grossa, Brasil}

\section{Jader Janer Moreira Lopes \\ Universidade Federal Fluminense e \\ Universidade Federal de Juiz de Fora, \\ Brasil \\ Debora Nunes \\ Universidade Federal do Rio Grande \\ do Norte, Brasil}

\section{Alda Junqueira Marin \\ Pontifícia Universidade Católica de \\ São Paulo, Brasil}

\section{Dalila Andrade Oliveira \\ Universidade Federal de Minas \\ Gerais, Brasil}

José Augusto Pacheco

Universidade do Minho, Portugal

Jane Paiva

Universidade do Estado do Rio de

Janeiro, Brasil

Paulo Alberto Santos Vieira

Universidade do Estado de Mato

Grosso, Brasil

Fabiany de Cássia Tavares Silva

Universidade Federal do Mato

Grosso do Sul, Brasil

António Teodoro

Universidade Lusófona

Portugal

Lílian do Valle

Universidade do Estado do Rio de

Janeiro, Brasil

\section{Alfredo Veiga-Neto}

Universidade Federal do Rio Grande

do Sul, Brasil 